Article

\title{
Chemical Composition and Biological Activities of Essential Oil from Salvia sclarea Plants Regenerated in vitro
}

\author{
Lukasz Kuźma ${ }^{1, *}$, Danuta Kalemba ${ }^{2}$, Marek Różalski ${ }^{3}$, Barbara Różalska ${ }^{4}$, \\ Marzena Więckowska-Szakiel ${ }^{4}$, Urszula Krajewska ${ }^{3}$ and Halina Wysokińska ${ }^{1}$
}

1 Department of Biology and Pharmaceutical Botany, Medical University of Łódź, Muszyńskiego 1, 90-151 Łódź, Poland; E-mail: botanika@pharm.am.lodz.pl (H.W.)

2 Institute of General Food Chemistry, Technical University of Łódź, Stefanowskiego 4/10, 90-924 Łódź, Poland; E-mail: dakal@snack.p.lodz.pl (D.K.)

3 Department of Pharmaceutical Biochemistry, Medical University of Łódź, Muszyńskiego 1, 90-151 Łódź, Poland; E-mails: mrozalski@pharm.am.lodz.pl (M.R.), ukrajewska@pharm.am.lodz.pl (U.K.)

4 Department of Immunology and Infectious Biology, Institute of Microbiology and Immunology, University of Łódź, Banacha 12/16, 90-237 Łódź, Poland; E-mail: rozab@biol.uni.lodz.pl (B.R.), mwiec@biol.uni.lodz.pl (M.W-S.)

* Author to whom correspondence should be addressed: E-mail: lukikuzma@wp.pl; Tel.: +48426779160; Fax: +48426779160 .

Received: 27 January 2009; in revised form: 23 February 2009 / Accepted: 26 February 2009 / Published: 2 April 2009

\begin{abstract}
The essential oils obtained by hydrodistillation of dried aerial parts of Salvia sclarea L. plants, regenerated in vitro and reproduced from seeds, were analyzed by GC and GC-MS. The oils from in vitro and in vivo plants were compared in respect to their chemical composition as well as antimicrobial and cytotoxic activities. The chemical profiles of both oils were very similar, although the yield of essential oil from in vitro plants was lower $(0.1 \%, \mathrm{v} / \mathrm{w})$ than the oil yield isolated from in vivo S. sclarea plants $(0.2 \%, \mathrm{v} / \mathrm{w})$. Both oils showed antimicrobial and cytotoxic activity. The oil from in vitro regenerated plants of $S$. sclarea exhibited stronger cytotoxic action against NALM-6 cell lines in comparison with the essential oil from in vivo plants.
\end{abstract}

Keywords: Salvia sclarea in vitro and in vivo; Essential oil chemical composition; Antimicrobial and cytotoxic activity. 


\section{Introduction}

The genus Salvia consists of many species, which have wide applications in folk medicine and also many commercial uses, especially in the production of essential oils and flavoring agents. Salvia sclarea L. (clary sage) is an example of such species. This plant, occurring in the Mediterranean basin and Iran [1], is one of the most important aromatic plants cultivated worldwide as a source of essential oils. The essential oils or extracts of the aerial part of the $S$. sclarea plant have a broad spectrum of effects: analgesic, antiinflammatory [2], antioxidant, antifungal [3], and antibacterial [4-5]. Apart from the various medicinal uses, essential oils of clary sage are widely applied in the food and cosmetic industries.

In vitro propagation techniques offer a powerful tool for mass multiplication of plants with a high level of secondary metabolites [6]. In the present study, we report on the yield and chemical composition of the essential oil isolated from S. sclarea plants obtained from shoot tip culture. For comparison, the essential oil from clary sage plants propagated from seeds was also isolated and analyzed. The essential oils isolated from in vitro- and in vivo-derived plants of S. sclarea were tested for their cytotoxic and antimicrobial activity. All the plants grew in the field under the same conditions and were collected at the same stage of development. Up to now, we have found no studies on essential oils produced by micropropagated plants of S. sclarea. In the literature, there have also been no attempts to investigate the chemical composition of essential oil of Salvia sclarea cultivated under Polish climatic conditions, although several studies on the composition of essential oils of the plant species cultivated in many other countries have been published [7-9].

\section{Results and Discussion}

The hydrodistillation of the aerial parts of S. sclarea in vitro and in vivo plants gave yellow oils in $0.1 \%$ and $0.2 \%\left(\mathrm{v} / \mathrm{w} ; \mathrm{ml} 100 \mathrm{~g}^{-1}\right.$ dry weight) yield, respectively. The chemical composition of the essential oils was analyzed by GC and GC-MS. Thus, eighty-two constituents were identified, representing about $96 \%$ of the total oils. The compounds, together with their retention indices and relative percentage concentrations are presented in Table 1, according to the elution order on the $\mathrm{CP}$ Sil 5 CB column. It was found that the chemical profiles of both oils were similar. The oils comprised 21 oxygenated monoterpenes (74\% and $75 \%$ in the oils from in vitro and in vivo plants, respectively), 13 monoterpene hydrocarbons $(8.8 \% ; 7.8 \%), 19$ sesquiterpene hydrocarbons $(6.6 \% ; 4.3 \%), 18$ oxygenated sesquiterpenes $(5.8 \% ; 6.4 \%)$, and 7 oxygenated diterpenes $(1.1 \% ; 2.2 \%)$ (Table 1$)$. The principal components of both oils were identified as linalool $(42.3 \%$ in the oil from in vitro plants and $38.6 \%$ in the oil from in vivo plants), $\alpha$-terpineol $(13.4 \% ; 14.3 \%)$, geraniol $(6.3 \% ; 7.7 \%)$, its acetate derivative $(5.4 \% ; 5.8 \%)$, and myrcene $(3.3 \% ; 3.4 \%)$. Linalool is one of the most useful monoterpene alcohols for the perfumery industry as well as for synthesis route to vitamin E [10]. Furthermore, this compound has exhibited antinociceptive [11], anticonvulsant [12] and sedative activities [13].

A major difference between the oils from in vitro and in vivo S. sclarea plants was observed only in the content of germacrene D; in the oil from micropropagated plants the amount of the sesquiterpene was almost four times higher than that found in the oil from in vivo plants. Similarity in the chemical composition of essential oils from in vitro and in vivo plants has been reported by some other authors [14-15]. For example, Fortunato and Avato (2008) [14] have reported that a chemical profile of the 
essential oil from Origanum vulgare L. ssp. hirtum in vitro plants was comparable to that of the control mother plants, with carvacrol as the main compound. On the other hand, comparative studies on the essential oils from in vitro and in vivo plants of Salvia przewalskii showed numerous differences between the two oil profiles [16]. We have found that the samples of oils studied by us were different from samples of oils obtained from S. sclarea plants grown for example in Greece, Spain, or Yugoslavia [7-8]. According to Souleles and Argyriadou (1997) [7], in the oil isolated from S. sclarea grown in Greece, 72 constituents were identified. Linalool was the main constituent of this oil, but its content (17.2\%) was over twice lower than that detected in essential oils isolated in the present study. In contrast, linalyl acetate was found in the essential oil from Greek clary sage in a higher amount (14.3\%) [7] as compared to the samples of oils analyzed in the present work (1.1-2.6\%). In the essential oil from aerial parts of S. sclarea growing in Yugoslavia [8], the percentage content of geraniol $(1.2 \%)$ was significantly lower than that in in vitro and in vivo clary sage plants examined in our work $(6.3 \% ; 7.7 \%)$. The sample of oil from plants growing in Spain showed an increased content of germacrene D (7.6\%) [7] in comparison with oils analyzed in our laboratory (Table 1). The changes in composition of oils could be related to climate or soil conditions.

The oils from in vitro and in vivo plants of S. sclarea were evaluated for their cytotoxicity and antimicrobial activity (Tables 2 and 3). Among the bacteria tested, Escherichia coli strain was the most sensitive microorganism to clary sage essential oils (Table 2). However, the significant activity was also noted against $S$. aureus and S. epidermidis strains (MIC values, respectively 10.0 and $5.0 \mathrm{mg} \mathrm{mL}^{-}$ ${ }^{1}$ ). The antimicrobial activity of the essential oils obtained from studied S. sclarea, propagated in vitro or in vivo, may well be due to the presence of synergy, antagonism or additive effects of the tested major components of the oils, which possess various potency of activity. Further studies are needed to explain which essential oils component, out of 82 main constituents demonstrated, are the most important one and is responsible for the bactericidal effects observed in this study.

As shown in Table 3 both oil samples tested exhibited cytotoxic activity against the NALM-6 and HL-60 cell lines, although the promyelocytic leukemia HL-60 cells were more sensitive to the essential oils $\left(\mathrm{IC}_{50}=6.5 \mu \mathrm{g} / \mathrm{mL}\right)$. The essential oil isolated from in vitro regenerated plants of $S$. sclarea had over 2-fold stronger cytotoxic activity against the NALM-6 cell line $\left(\mathrm{IC}_{50}=8.1 \mu \mathrm{g} / \mathrm{mL}\right)$ than the volatile oil obtained from in vivo clary sage plants $\left(\mathrm{IC}_{50}=20.1 \mu \mathrm{g} / \mathrm{mL}\right)$. This difference was statistically significant with $p$ value less than 0.01 , as calculated by Student's $t$-test. Higher cytotoxic activity could be explained with a higher content of germacrene $\mathrm{D}$ in the oil isolated from in vitro plants (Table 1). Antiproliferative activity of the sesquiterpene against the MDA-MB-231, MCF7, Hs 578T, PC-3 and Hep-G2 cell lines has been reported by Setzer et al. (2006) [17]. Germacrene D has exhibited a 7-fold stronger cytotoxic activity against the Hs 578T cell line in comparison with $\alpha$ pinene and limonene and a 6-fold stronger action against Hs 578T and Hep-G2 than 1,8-cineole, linalool, 4- terpineol and $\alpha$-terpineol [17]. 
Table 1. Constituents of essential oils from in vitro/in vivo Salvia sclarea plants.

\begin{tabular}{|c|c|c|c|c|}
\hline Peak number & Compound & RI & $V(\%)$ & $\mathrm{S}(\%)$ \\
\hline 1. & $\alpha$-thujene & 926 & 0.1 & $\mathrm{t}$ \\
\hline 2. & $\alpha$-pinene & 935 & $\mathrm{t}$ & $\mathrm{t}$ \\
\hline 3. & camphene & 950 & 0.1 & 0.1 \\
\hline 4. & $\beta$-pinene & 974 & 0.2 & $\mathrm{t}$ \\
\hline 5. & myrcene & 983 & 3.3 & 3.4 \\
\hline 6. & $\alpha$-phellandrene & 999 & 0.1 & 0.1 \\
\hline 7. & $\alpha$-terpinene & 1012 & $\mathrm{t}$ & $\mathrm{t}$ \\
\hline 8. & p-cymene & 1116 & 0.1 & 0.1 \\
\hline 9. & limonene & 1025 & 1.0 & 0.9 \\
\hline 10. & $(Z)-\beta$-ocimene & 1031 & 1.0 & 0.9 \\
\hline 11. & $(E)$ - $\beta$-ocimene & 1041 & 2.1 & 1.8 \\
\hline 12. & $\gamma$-terpinene & 1055 & 0.2 & 0.1 \\
\hline 13. & trans-sabinene hydrate & 1060 & $\mathrm{t}$ & $\mathrm{t}$ \\
\hline 14. & trans-linalool oxide & 1062 & $\mathrm{t}$ & $\mathrm{t}$ \\
\hline 15. & fenchone & 1070 & 0.1 & 0.1 \\
\hline 16. & cis-linalool oxide & 1076 & $\mathrm{t}$ & $\mathrm{t}$ \\
\hline 17. & terpinolene & 1083 & 0.6 & 0.4 \\
\hline 18. & linalool & 1087 & 42.3 & 38.6 \\
\hline 19. & endo-fenchol & 1100 & 0.2 & 0.2 \\
\hline 20. & camphor & 1126 & $\mathrm{t}$ & $\mathrm{t}$ \\
\hline 21. & pinocamphone & 1139 & 0.1 & 0.1 \\
\hline 22. & borneol & 1155 & 0.1 & $\mathrm{t}$ \\
\hline 23. & terpinen-4-ol & 1166 & 0.2 & 0.1 \\
\hline 24. & $\alpha$-terpineol & 1178 & 13.4 & 14.3 \\
\hline 25. & myrtenol & 1178 & $\mathrm{t}$ & $\mathrm{t}$ \\
\hline 26. & p-menth-1-en-9-al & 1188 & $\mathrm{t}$ & $\mathrm{t}$ \\
\hline 27. & $\beta$-cyclocitral & 1195 & $\mathrm{t}$ & $\mathrm{t}$ \\
\hline 28. & nerol & 1213 & 2.3 & 2.5 \\
\hline 29. & piperitone & 1232 & $\mathrm{t}$ & $\mathrm{t}$ \\
\hline 30. & geraniol & 1238 & 6.3 & 7.7 \\
\hline 31. & linalyl acetate & 1242 & 1.1 & 2.6 \\
\hline 32. & neryl formate & 1268 & 0.1 & $\mathrm{t}$ \\
\hline 33. & bicycloelemene & 1339 & 0.2 & 0.1 \\
\hline 34. & neryl acetate & 1344 & 2.8 & 3.0 \\
\hline 35. & $\alpha$-cubebene & 1355 & 0.1 & 0.1 \\
\hline 36. & $(E)$ - $\beta$-damascenone & 1362 & $\mathrm{t}$ & $\mathrm{t}$ \\
\hline 37. & geranyl acetate & 1363 & 5.4 & 5.8 \\
\hline 38. & $\alpha$-copaene & 1379 & 1.3 & 1.2 \\
\hline 39. & $\beta$-bourbonene & 1386 & 0.2 & 0.2 \\
\hline 40. & $\beta$-elemene & 1390 & 0.3 & 0.1 \\
\hline
\end{tabular}


Table 1. Cont.

\begin{tabular}{|c|c|c|c|c|}
\hline 41. & $\alpha$-cedrene & 1418 & 0.1 & 0.1 \\
\hline 42. & $\beta$-caryophyllene & 1420 & 1.1 & 1.1 \\
\hline 43. & geranylacetone & 1430 & 0.1 & $\mathrm{t}$ \\
\hline 44. & calarene & 1437 & $\mathrm{t}$ & $\mathrm{t}$ \\
\hline 45. & isogermacrene D & 1445 & 0.1 & $\mathrm{t}$ \\
\hline 46. & $(Z)$ - $\beta$-farnesene & 1448 & $\mathrm{t}$ & $\mathrm{t}$ \\
\hline 47. & $\alpha$-humulene & 1453 & 0.1 & 0.1 \\
\hline 48. & (E)- $\beta$-farnesene & 1475 & $\mathrm{t}$ & $\mathrm{t}$ \\
\hline 49. & $\beta$-ionone & 1477 & 0.2 & 0.2 \\
\hline 50. & germacrene D & 1480 & 2.2 & 0.6 \\
\hline 51. & $\beta$-selinene & 1484 & $\mathrm{t}$ & 0.1 \\
\hline 52. & bicyclogermacrene & 1493 & 0.3 & 0.1 \\
\hline 53. & cubebol & 1514 & 0.1 & 0.1 \\
\hline 54. & trans-calamenene & 1514 & $\mathrm{t}$ & $\mathrm{t}$ \\
\hline 55. & $\delta$-cadinene & 1516 & 0.3 & 0.2 \\
\hline 56. & $\alpha$-calacorene & 1527 & 0.2 & 0.2 \\
\hline 57. & salviadienol & 1540 & 0.1 & 0.2 \\
\hline 58. & $\beta$-calacorene & 1541 & 0.1 & 0.1 \\
\hline 59. & mintoxide & 1545 & $\mathrm{t}$ & $\mathrm{t}$ \\
\hline 60. & spathulenol & 1569 & 1.5 & 1.1 \\
\hline 61. & caryophyllene oxide & 1573 & 1.4 & 2.2 \\
\hline 62. & salvial-4(14)en-1-one & 1584 & 0.4 & 0.3 \\
\hline 63. & humulene epoxide II & 1587 & 0.1 & 0.1 \\
\hline 64. & torilenol & 1601 & 0.1 & 0.1 \\
\hline 65. & cedrol & 1602 & 0.2 & 0.2 \\
\hline 66. & 12-epi-cedrol & 1620 & 0.1 & 0.1 \\
\hline 67. & humulene epoxide III & 1624 & 0.2 & 0.2 \\
\hline 68. & T-cadinol & 1633 & 0.2 & 0.1 \\
\hline 69. & $\beta$-eudesmol & 1641 & 0.5 & 0.6 \\
\hline 70. & $\alpha$-eudesmol & 1651 & 0.3 & 0.3 \\
\hline 71. & eudesma-4(15),7-dien-1 $\beta$-ol & 1671 & 0.3 & 0.4 \\
\hline 72. & $\alpha$-bisabolol & 1673 & 0.1 & 0.1 \\
\hline 73. & $(Z, Z)$-farnesol & 1685 & 0.1 & 0.2 \\
\hline 74. & $(E, E)$-farnesol & 1706 & 0.1 & 0.1 \\
\hline 75. & (E)-2,6-dimethyl-10-(p-tolyl)-undeca-2,6-diene & 1945 & 0.2 & 0.3 \\
\hline 76. & manoyl oxide & 2007 & 0.4 & 0.6 \\
\hline 77. & 13-epi-manoyl oxide & 2023 & 0.2 & 0.2 \\
\hline 78. & manool & 2070 & 0.1 & 0.3 \\
\hline 79. & 13-epi-manool & 2080 & 0.2 & 0.4 \\
\hline 80. & labda-7,14-dien-13-ol & 2096 & 0.1 & 0.1 \\
\hline 81. & isoabienol & 2124 & $\mathrm{t}$ & $\mathrm{t}$ \\
\hline 82. & sclareol & 2231 & 0.1 & 0.6 \\
\hline
\end{tabular}


Table 1. Cont.

\begin{tabular}{lll} 
Oxygenated monoterpenes & 74.4 & 75.0 \\
Monoterpene hydrocarbons & 8.8 & 7.8 \\
Sesquiterpene hydrocarbons & 6.6 & 4.3 \\
Oxygenated sesquiterpenes & 5.8 & 6.4 \\
Oxygenated diterpenes & 1.1 & 2.2 \\
Other components & 0.5 & 0.5 \\
Total & 97.2 & 96.2 \\
\hline
\end{tabular}

RI - Relative retention index on CP Sil 5 CB column; V - essential oil from in vitro plants;

$\mathrm{S}$ - essential oil from in vivo plants; $\mathrm{t}$ - trace (percentage value less than $0.01 \%$ ).

Table 2. Antimicrobial activity of S. sclarea essential oils. MIC values were determined by the microdilution assay, according to CLSI recommendations.

\begin{tabular}{|c|c|c|c|}
\hline \multirow{3}{*}{ Microorganism } & \multicolumn{3}{|c|}{ MIC } \\
\hline & \multicolumn{2}{|c|}{$\left[\mathrm{mg} \mathrm{m} \mathbf{L}^{-1}\right]$} & \multirow{2}{*}{$\begin{array}{c}{\left[\mu \mathrm{g} \mathrm{mL}^{-1}\right]} \\
\text { Control }\end{array}$} \\
\hline & $\mathbf{V}$ & $\mathbf{S}$ & \\
\hline Staphylococcus aureus (ATCC 29213) & $>5.0$ & 10.0 & $1.0(\mathrm{~A})$ \\
\hline Staphylococcus epidermidis (ATCC 12228) & $>5.0$ & 5.0 & $8.0(\mathrm{~A})$ \\
\hline Enterococcus faecalis (ATCC 29212) & $>5.0$ & $>10.0$ & $1.0(\mathrm{~A})$ \\
\hline Escherichia coli (NCTC 8196) & $>5.0$ & 2.5 & $0.015(\mathrm{O})$ \\
\hline Pseudomonas aeruginosa (NCTC 6749) & $>5.0$ & $>10.0$ & $2.0(\mathrm{O})$ \\
\hline Candida albicans (ATCC 10231) & $>5.0$ & $>10.0$ & $8.0(\mathrm{I})$ \\
\hline
\end{tabular}

MIC - Minimum inhibitory concentration; V - In vitro plants; S - In vivo plants; Control antimicrobial agents: (A) - ampicillin; (O) - ofloxacin; (I) - itraconazole

Table 3. Cytotoxic activity of $S$. sclarea essential oils. $\mathrm{IC}_{50}$ values were determined by the MTT assay.

\begin{tabular}{ccc} 
Essential oil & HL-60 & $\begin{array}{c}\text { NALM-6 } \\
\mathbf{I C}_{\mathbf{5 0}}\left[\boldsymbol{\mu} \mathbf{g} \mathbf{~ m L}^{-\mathbf{1}}\right]\end{array}$ \\
\hline $\mathrm{V}$ & $6.5 \pm 0.3$ & $8.1 \pm 0.7$ \\
$\mathrm{~S}$ & $6.4 \pm 0.4$ & $20.1 \pm 3.4$ \\
\hline
\end{tabular}

$\mathbf{I C}_{\mathbf{5 0}}$ - The concentration of the tested oil required to reduce the cell survival fraction to $50 \%$ of the control; V - In vitro plants; S - In vivo plants

\section{Conclusions}

Our studies have shown that the yield of the oil isolated from in vitro plants of S. sclarea at the flowering stage was slightly lower to that of in vivo plants. However, the chemical profile and relative amounts of compounds were very similar in both oils. These results strongly suggest that using in vitro 
propagated plants of S. sclarea as a source of essential oil is possible. It is important in view of the biological activity and commercial application of the essential oil.

\section{Experimental}

\section{Plant material}

According to the reported procedure [18], shoots of Salvia sclarea were multiplied from shoot tips on solid (0.7\% agar) Murashige and Skoog (MS) medium [19] supplemented with indole-3-acetic acid (IAA) $\left(0.1 \mathrm{mg} \mathrm{L}^{-1}\right)$, 6-benzylaminopurine (BAP) $\left(1.0 \mathrm{mg} \mathrm{L}^{-1}\right)$ and sucrose (3\%). For rooting, axillary shoots were transferred on agar MS medium without growth regulators. Cultures were maintained in the growth room at $26 \pm 2{ }^{\circ} \mathrm{C}$ and $70 \%$ humidity with photoperiod of $16 \mathrm{~h}$ of light $/ 8 \mathrm{~h}$ of darkness. Illumination was supplied by cool white fluorescent lamps with a light intensity of $40 \mu \mathrm{mol} \mathrm{m}^{-2} \mathrm{~s}^{-1}$. Four-week-old rooted shoots were transferred to the pots with the sterile mixture of soil, sand and peat (4:3:3) and grown under greenhouse conditions, at $24{ }^{\circ} \mathrm{C}$. After acclimatization stage (3 weeks), plantlets were grown for two years in the field (Medicinal Plant Garden of the Medical University of Łódź). They were referred to as in vitro plants. For comparison, Salvia sclarea plants propagated from seeds and cultivated under the same conditions as in vitro plants were also investigated. They were referred to as in vivo plants. For analysis, S. sclarea plants in vitro and in vivo were two years old. Aerial parts of the plants were collected at the flowering stage.

\section{Isolation of essential oil}

The essential oil was obtained by hydrodistillation of the air-dried aerial parts of in vitro and in vivo plant materials (shoots and flowers) (ca $140 \mathrm{~g}$ dry weight) using a Clevenger-type apparatus for $5 \mathrm{~h}$.

\section{GC and GC-MS analyses}

The GC analysis of the essential oil samples was performed using a Carlo-Erba Vega 6000 apparatus equipped with an FID detector and a capillary column CP Sil 5 CB (30 m × $0.32 \mathrm{~mm}$ i.d., film thickness $0.25 \mu \mathrm{m}$, Quadrex Corporation, New Haven). The oven temperature was programmed as follows: $60-300{ }^{\circ} \mathrm{C}$ at $4{ }^{\circ} \mathrm{C} / \mathrm{min}$ and the final temperature was held for $10 \mathrm{~min}$; injector temperature $320{ }^{\circ} \mathrm{C}$; detector temperature $310{ }^{\circ} \mathrm{C}$; carrier gas $\mathrm{N}_{2}$ at a flow rate of $1.5 \mathrm{ml} \mathrm{min}^{-1}$. Peaks were measured by electronic integration. The percentage composition of the essential oil samples was computed from the peak areas using the normalization method. The GC-MS analysis was carried out with a Fison MD 800 mass spectrometer (ion source $200{ }^{\circ} \mathrm{C}$, EI $70 \mathrm{eV}$ ) connected to a GC 8000 gas chromatograph; helium served as the carrier gas with a flow rate of $0.8 \mathrm{~mL} \mathrm{~min}^{-1}$. A CP Sil $5 \mathrm{CB}$ column was used at the same parameters as described for GC. The identification of compounds was based on the comparison of their retention indices and mass spectra with those in commercial libraries NIST 98.1 and MassFinder 3.1. The results are presented in Table 1. 


\section{Biological activity of essential oils}

For antibacterial and antifungal activity testing, three Gram-positive bacteria: Staphylococcus aureus ATCC 29213, Staphylococcus epidermidis ATCC 12228, Enterococcus faecalis ATCC 29212; two Gram-negative bacteria: Escherichia coli NCTC 8196, Pseudomonas aeruginosa NCTC 6749 and yeast Candida albicans ATCC 10231 were used. The susceptibility of microorganisms to essential oils was determined by the standard CLSI (Clinical Laboratory Standards Institute) microdilution method. Sterile stock solutions of each oil at the concentration of $160 \mathrm{mg} \mathrm{mL}^{-1}$ were prepared in dimethyl sulphoxide (DMSO). The oils concentration range used was $10.0-0.15 \mathrm{mg} \mathrm{mL}^{-1}$, prepared for bacteria in Mueller-Hinton broth (Difco), and for yeast in RPMI-1640 medium supplemented with L-glutamine and $\mathrm{NaHCO}_{3}$ (Biomed, Poland). Overnight grown bacterial suspensions were standarized to $10^{6} \mathrm{CFU}$

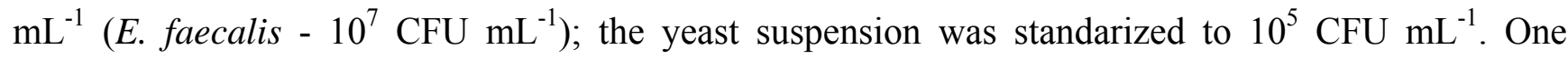
hundred $\mu \mathrm{L}$ of each suspension was added to the wells containing essential oils serial dilutions (in triplicate). The oils solubilizer was used as a growth control (no antimicrobial activity was noted). The culture medium was used as a blank control. The following standard antibacterial/antifungal agents were used: ampicillin (Serva), ofloxacin (Sigma), itraconazole (Jansen-Cilag Int., N.V.). After incubation at $37^{\circ} \mathrm{C}, 24 \mathrm{~h}$ (bacteria) and at $28^{\circ} \mathrm{C}, 48 \mathrm{~h}$ (yeast), turbidometric $\left(\mathrm{OD}_{600}\right)$ measures were carried out using the multifunction counter Victor2 (Wallac, Finland) and the minimal inhibitory concentrations (MICs) were specified. The results are shown in Table 2.

\section{Cytotoxic activity of essential oils}

Cytotoxic activity of $S$. sclarea essential oils was determined by the MTT [3-(4,5-dimethylthiazol2-yl)-2,5-diphenyltetrazolium bromide; Sigma, St. Louis, USA] assay [20]. Human leukemia promyelocytic HL-60 and lymphoblastic NALM-6 cell lines were used. More details about the cell lines and methods of cytotoxicity assay have been described previously by Różalski et al. (2006) [21]. The results are shown in Table 3.

\section{Acknowledgements}

This work was supported by the Medical University of Lodz (502-13-543 to M. R.).

\section{References and Notes}

1. Dweck, A.C. The folklore and cosmetics use of vatious Salvia species. In Sage. The genus Salvia; Kintzios, S.E., Ed.; Harwood Academic Publishers: Amsterdam, The Netherlands, 2000; pp. 1-25.

2. Moretti, M.D.L.; Peana, A.T.; Satta, M.A. A study of antiinflammatory and peripheral analgesic actions of Salvia sclarea oil and its main constituents. J. Essent. Oil. Res. 1997, 9, 199-204.

3. Pitarokili, D.; Couladis, M.; Petsikos-Panayotarou, N.; Tzakou, O. Composition and antifungal activity on soil-borne pathogens of the essential oil of Salvia sclarea from Greece. J. Agric. Food Chem. 2002, 50, 6688-6691.

4. Peana, A.T.; Moretti, M.D.; Juliano, C. Chemical composition and antimicrobial action of the essential oils of Salvia desoleana and S. sclarea. Planta Med. 1999, 65, 752-754. 
5. Gülçin, I. Evaluation of the antioxidant and antimicrobial activities of clary sage (Salvia sclarea L.). Turk. J. Agric. For. 2004, 28, 25-33.

6. Piątczak, E.; Wielanek, M.; Wysokińska, H. Liquid culture system for shoot multiplication and secoiridoid production in micropropagated plants of Centaurium erythraea Rafn. Plant Sci. 2005, 168, 431-437.

7. Souleles, Ch.; Argyriadou, N. Constituents of essential oil of Salvia sclarea growing wild in Greece. Int. J. Pharm. 1997, 35, 218-220.

8. Giannouli, A.L.; Kintzios, S.E. Essential oils of Salvia spp.: Examples of intraspecific and seasonal variation. In Sage. The genus Salvia; Kintzios, S.E., Ed.; Harwood Academic Publishers: Amsterdam, The Netherlands, 2000; pp. 69-79.

9. Lawrence, B.M. Production of clary sage oil and sclareol in North America. Proc. Of Remes Recontres Internationales Nyons, 1994; pp. 41-48.

10. Frighetto, N.; de Oliveira, J.G.; Siani, A.C.; das Chagas, K.C. Lippia alba Mill N.E. Br. (Verbenaceae) as a source of linalool. J. Essent. oil. Res. 1998, 10, 578-580.

11. Batista, P.A.; Werner, M.F.P.; Oliveira, E.C.; Burgos, L.; Pereira, P.; Brum, L.F.S.; Santos, A.R.S. Evidence for the involvement of ionotropic glutamatergic receptors on the antinociceptive effect of (-)-linalool in mice. Neurosci. Lett. 2008, 440, 299-303.

12. Elisabetsky, E.; Brum, L.F.; Souza, D.O. Anticonvulsant properties of linalool in glutamaterelated seizure models. Phytomedicine 1999, 6, 107-113.

13. Sugawara, Y.; Hara, C.; Tamura, K.; Furii, T.; Nakamura, K.; Masujima, T.; Aoki, T. Sedative effect on humans of inhalation of essential oil of linalool: - Sensory evaluation and physiological measurements using optically active linalools. Anal. Chim. Acta 1998, 365, 293-299.

14. Fortunato, I.M.; Avato, P. Plant development and synthesis of essential oils in micropropagated and mycorrhiza inoculated plants of Origanum vulgare L. ssp. hirtum (Link) Ietswaart. Plant Cell Tiss. Org. Cult. 2008, 93, 139-149.

15. Chebel, A.V.; Koroch, A.R.; Juliani, H.R.; Juliani, H.R.; Trippi, V.S. Micropropagation of Minthostachys mollis (H.B.K.) grieseb. and essential oil composition of clonally propagated plants. In Vitro Cell. Dev. Biol.-Plant 1998, 34, 249-251.

16. Skała, E.; Kalemba, D.; Wajs, A.; Różalski, M.; Krajewska, U.; Różalska, B.; WięckowskaSzakiel, M.; Wysokińska, H. In vitro propagation and chemical and biological studies of the essential oil of Salvia przewalskii Maxim. Z. Naturforsch. 2007, 62c, 839-848.

17. Setzer, W.N.; Schmidt, J.M.; Noletto, J.A.; Vogler, B. Leaf oil compositions and bioactivities of abaco bush medicines. Pharmacologyonline 2006, 3, 794-802.

18. Skała, E.; Wysokińska, H. Mikrorozmnażanie Salvia sclarea L. i Salvia splendens Ker.-Gawl. Ann. UMCS Sect. EEE 2001, 9, 319-325.

19. Murashige, T.; Skoog, F. A revised medium for rapid growth and bioassays with tobacco tissue cultures. Physiol. Plant. 1962, 15, 473-497.

20. Hansen, M.B.; Nielsen, S.E.; Berg, K. Re-examination and further development of a precise and rapid dye method for measuring cell growth/cell kill. J. Immunol. Methods 1989, 119, 203-210. 
21. Różalski, M.; Kuźma, Ł.; Krajewska, U.; Wysokińska, H. Cytotoxic and proapoptotic activity of diterpenoids from in vitro cultivated Salvia sclarea roots. Studies on the leukemia cell lines. Z. Naturforsch. 2006, 61c, 483-488.

Sample Availability: Samples of the essential oils are available from authors (or from MDPI).

(C) 2009 by the authors; licensee Molecular Diversity Preservation International, Basel, Switzerland. This article is an open-access article distributed under the terms and conditions of the Creative Commons Attribution license (http://creativecommons.org/licenses/by/3.0/). 